\title{
The Effect of Multisensory Method on Children Language Development
}

\author{
Kurnia Oktafianto, Siti Masitoh, Hendratno \\ Universitas Negeri Surabaya \\ Surabaya, Indonesia \\ lautkuning@gmail.com
}

\begin{abstract}
This study aims to analyze the effect of multisensory method on language development for kindergarten students. Researchers choose a multisensory method to help 5-6 years old children in understanding early literacy. Multisensory method has the principle of teaching that involves several modalities of sense devices, including visual, auditory, kinesthetic, and tactile. This research is included in a quantitative approach with quasi experimental research. The subjects of this research are 40 kindergarten students. Technique to obtain the data uses an observation. Data analysis technique used in this research is an independent sample t-test. The results of this research revealed that the multisensory method has a strong influence on the language of the children on the kindergarten level in Bangkalan. The language development in the experimental group shows a better result than the control group. It is expected that kindergarten teachers can utilize this method to maximize the language skills of children in kindergarten level that aged 5-6 years old.
\end{abstract}

Keywords-Multisensory, Language, Kindergarten

\section{INTRODUCTION}

Education for children at an early age is an education that is intended to optimize all the developments that exist in a child, it certainly very needs stimulation, cooperation, and guidance from various parties, namely schools, parents, and communities in the neighborhood.

Early childhood education is important for children, as it can be a preparation for the next level of education. [1] Hasan reveals that early childhood education is a level of education before basic education aimed at fostering children from birth up to the age of six years with the provision of educational stimuli to help stimulate growth and spiritual and physical growth so that children have readiness in entering a further education.

Guidance counseling through early childhood education that is shown for children should be given so that later children can develop aspects of development [2]. Aspects to be developed in early childhood education as the fourth set in the Ministry of Education and Culture of the Republic of Indonesia No.137 of 2014 on National Standards of Early Childhood Education include six developments which include the development of religious and moral values, social-emotional, cognitive, language, physical motor, and art.

Language development is one of the basic skills that must have by the children. Language is a social formation because the children acquire the language from interaction with other people around them. In the standard of achievement level of children listed in Permendikbud No. 137 year 2014, language ability of children aged 5-6 years includes literacy aspect that involves mentioning the symbols of known letters and understanding the relationship between the sound and the letter form.

Susanto states [3] that one of the developments of language for children is the development of literacy. Early childhood literacy can be divided into four stages of development, namely the stage of awareness of writing, the stage of reading the picture, the stage of reading recognition and the stage of reading fluently. Gray distinguishes three categories of literacy, the narrow category, rather broad category and broad category. Children on Kindergarten level are included in the narrow category, starting with the introduction of a reading or a writing symbol to know the letters and recognize syllables. Glen also explained that in early childhood begins with the introduction of letters, recognize the syllables and then to know the words. Frequency of reading a book, especially every day, and children's exposure to books can improve their initial literacy skills.

According to Sintayani, the understanding and knowing letters and series of letters such as syllables as well as sounds and skillfully turns them into sounds is a stage in children of Kindergarten level. Aulia also explained that at the age of kindergarten [4], it should be given the basics of reading recognition mechanisms such as associate the letters with the sounds of the language it represents and then the letters are strung into a syllable. From the description above, it can be concluded that the activity of recognizing syllables related to the introduction of symbols of letters or characters and sounds of symbols of letters or script that skillfully children can change the letters into sound and ending into syllables. 
Initial field observation results are found that a low level of early literacy understanding in children group B in group II of Bangkalan district. This is known because the learning activities used are still less varied so that the expected ability does not develop with the maximum.

One of the activities that support early childhood literacy skills is the multisensory method. Fernald and Gillingham have developed a multisensory reading teaching method often known as the VAKT method [5]. The multisensory approach based on the assumption that the child will learn better if the subject matter is presented in various modalities. Modalities often involved are visual (sight), auditory (hearing), kinesthetic (movement), and tactile (touch), which is often called VAKT.

This method is one of the remedial reading programs for dyslexic children, but it is felt that some principles in this method can be applied, and is expected to overcome some obstacles in the implementation of literacy activities in kindergarten. Furthermore, the researchers assume that the multisensory application can utilize flannel board media, letter cards, and sand media for the implementation of its activities.

The findings that are relevant to this research are the research [6] that has been conducted by Labat under the heading "How can a five-year-old who has low skills get benefit from multisensor training on alphabetical acquisition?" The aim of this study is to evaluate the effect of letters knowledge and the exploration of multisensory writing on letters on the function of a skill level of children (low skill vs high). The study shows that a significant percentage increases for children who use visual, visuohaptic (touching finger-by-finger) learning approaches, and visuo-graphomotor.

The next findings are revealed by Tri Kemala Mutia on the influence of multisensory method in improving the ability to memorize the word in children of hearing impaired kindergarten who showed a significant influence in improving the ability to memorize the word in children with hearing impaired using a multisensory method.

Another study is conducted by Ruhaena on the use of multisensory models for early children literacy activities at home. The study is conducted on 56 mothers and children. And it found [7] that the multisensory model generated a positive atmosphere to attract children and to encourage mother involvement in literacy activities. The benefits of an affective interaction are also obtained. Therefore, it is strongly recommended to apply a multisensory model in early childhood literacy recognition.

Based on the above description, it is necessary to study the development of language for children of group B in Kindergarten by using a multisensory method as a refinement of previous studies. So, the researchers want to know the extent of the influence of this method if it is applied to children in formal schools, as well as giving these children the opportunity to develop language skills optimally according to interest and age. Furthermore, based on the background and description above the need for research on the influence of multisensory methods on the language and fine motor skills of children group B Kindergarten in Bangkalan.

\section{METHOD}

This study uses a quantitative approach with the type of experimental research, namely to determine whether there is a result of something [8] that was introduced in the sample research. This research uses an experimental research. The subjects of this research are 40 students aged 5-6 years old in TK ABA 01 Bangkalan. From the description above, the selected subjects are divided into two, namely 20 experimental class children and 20 children of the control class.

Research instrument used in this research is [9] an observation that is done by using sheets of observation. In order to use the instrument appropriately, the researchers need to make a lattice.

TABLE I. LATTICES OF RESEARCH INSTRUMENTS DEVELOPING LITERACY

\begin{tabular}{|l|l|l|}
\hline \multicolumn{1}{|c|}{$\begin{array}{c}\text { Level of } \\
\text { achievement }\end{array}$} & Indicators & \multicolumn{1}{c|}{ Activities } \\
\hline $\begin{array}{l}\text { Mention the } \\
\text { letter symbols } \\
\text { known }\end{array}$ & $\begin{array}{l}\text { Get to } \\
\text { know the } \\
\text { wide range } \\
\text { of vowels } \\
\text { and } \\
\text { consonants }\end{array}$ & $\begin{array}{l}\text { 1. Mention vowels } \\
\text { 2. Mention } \\
\text { consonants } \\
\text { 3. Impersonate the } \\
\text { pronunciation of } \\
\text { letters that make-up } \\
\text { words in } \\
\text { sequence }\end{array}$ \\
\hline $\begin{array}{l}\text { Understand the } \\
\text { relationship } \\
\text { between } \\
\text { sounds and } \\
\text { letters form }\end{array}$ & $\begin{array}{l}\text { Get to } \\
\text { know the } \\
\text { simple } \\
\text { syllables }\end{array}$ & $\begin{array}{l}\text { Mention a syllable that } \\
\text { consists of two series } \\
\text { of letters }\end{array}$ \\
\hline
\end{tabular}

The scale used in this study is the rating scale presented from 1-4 written with an asterisk. The use of an asterisk is a symbol to show the level of child development achievement as a result of teacher observation.

This research uses an independent sample t-test as the data analysis technique. The independent sample t-test compares the means of two independent groups in order to determine whether there is statistical evidence [10] that the associated population means are significantly different. The independent sample t-test is a parametric test.

\section{RESULTS AND DISCUSSION}

Early observations are conducted previously by observing language development in terms of literacy development. The initial observations are made by looking 
at the language development in terms of literacy development. This observation is carried out to determine the extent of children's language skills so that problems and ways to overcome them can be known.

TABLE II. PRE-TEST TEST OF LANGUAGE DEVELOPMENT IN THE CONTROL AND EXPERIMENTAL GROUP

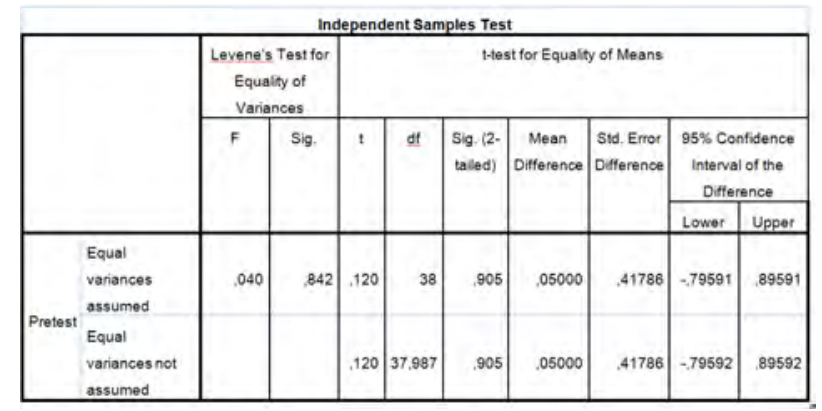

Based on the results of the calculation of statistics with independent test sample t-test in the table above, it can be aware that the value of the significance or $p$ value $0.05>$ 0.905. It means that there is no significant difference in the average pre-test language skills between the experimental and control group.

The observations of the post-test are done after the experiment class gets a treatment of multisensory method and the control class gets lesson activities as usual.

\section{TABLE III. AVERAGE TEST}

\begin{tabular}{|r|l|r|r|r|r|}
\hline \multicolumn{7}{|c|}{ Group Statistics } \\
\hline \multirow{2}{*}{ Posttest } & Kelompok & \multicolumn{1}{c|}{$\mathrm{N}$} & \multicolumn{1}{c|}{ Mean } & \multicolumn{1}{c|}{ Std. Deviation } & \multicolumn{1}{c|}{ Std. Error Mean } \\
\cline { 2 - 7 } & Eksperimen & 20 & 13.7500 & 1.77334 & .39653 \\
& Kontrol & 20 & 11.5000 & 2.16430 & .48395 \\
\hline
\end{tabular}

Based on the results of the calculation of the statistics on the table above, it can be seen the average value and standard deviation of each group. The average of experimental group is higher than the control group. It is done to find out whether these differences are significant or not, then it can be seen on the results of the independent samples t-test here.

TABLE IV. POST-TEST OF LANGUAGE DEVELOPMENT IN CONTROL AND EXPERIMENTAL GROUP

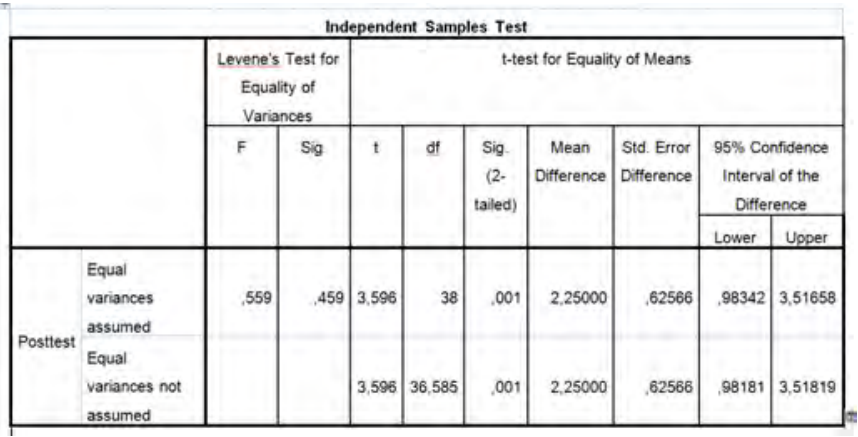

Based on the results of the calculation of statistics with independent test sample t-test on the table above, it can be noted that the value of the significance or $p$ value $0.001<$
0.05. It means that there is a difference in the significance of post-test average language proficiency between experimental and control group.

The researchers reveal that the multisensory Method affects the language development in children of kindergarten level in Bangkalan. Expressive language development in the experimental group is better than the control group. It also agreed with Lisnawati research, multisensory model brought up the positive atmosphere to attract the interest of children and to encourage mother engagement in literacy activities. The benefit of effective interaction also is obtained. Therefore, it is highly recommended to apply multisensory model in a larger community.

\section{CONCLUSION}

Based on the results of the research, it can be concluded that multisensory method can give a significant influence in improving the language skills of children in kindergarten level. Language skills in the experimental group are higher than the control group. In the table, the significance or $p$ value is $0.001<0.05$. It can be meant that there is a significant difference in post-test mean language ability between experiment and control group. Thus, it can be concluded that the multisensory method has an influence on the development of the child language. The results of the analysis show that a hypothesis "multisensory method has an effect on the development of child language in kindergarten" is accepted.

In the multisensory method, the stimulus is presented in multiple modalities all at once in order to be able to overcome the differences in learning styles of children in a regular class. For the granting of preferential treatment, the multisensory method is given uniformly on all subjects. The implementation of principle of this method should include the four sessions of visual excitation - auditory, tactile, kinesthetic excitation, and recall to overcome the difference in capturing children's ability of learning stimuli.

It is expected for kindergarten teachers to take advantage of this method to the maximum so that the children are able to maximize their literacy skills in particular, that becomes the provision on secondary education.

\section{REFERENCES}

[1] M. Hasan, "Pendidikan anak usia dini," Yogyakarta: DIVA, 2009.

[2] B. Zaman, "Peraturan Menteri Pendidikan dan Kebudayaan Republik Indonesia Nomor 137 tahun 2014 tentang Standar Nasional Pendidikan Anak Usia Dini," Jakarta: Departemen Pendidikan dan Kebudayaan Nasional, 2014.

[3] A. Nuraeni, "Peran Orang Tua dalam Pengembangan Literasi Dini Anak Kelompok B di Gugus 7 Mangunan Dlingo Bantul," Pendidikan Guru PAUD S-1, vol. 5, pp. 245-256, 2016.

[4] R. Aulia, "Meningkatkan Kemampuan Membaca Pemahaman pada Anak. Tunarungu," Jurnal Ilmiah Pendidikan Khusus, vol. 1, 2012.

[5] M. Yusuf, "Pendidikan bagi anak dengan problema belajar," Jakarta: Depdikbud, 2005. 
[6] H. Labat, J. Ecalle, R. Baldy, and A. Magnan, "How can lowskilled 5-year-old children benefit from multisensory training on the acquisition of the alphabetic principle?," Learning and Individual Differences, vol. 29, pp. 106-113, 2014.

[7] L. Ruhaena, "Model Multisensori: Solusi Stimulasi Literasi Anak Prasekolah," Jurnal Psikologi, vol. 42, pp. 47-60, 2015.

[8] A. S. Hamdi and E. Bahruddin, Metode penelitian kuantitatif aplikasi dalam pendidikan: Deepublish, 2015.

[9] $\quad$ L. J. Moleong, "Metodologi penelitian," Bandung: PT. Remaja Rosda Karya, 1999.

[10] W. Purnomo, "Uji t Sampel Berpasangan," Handout MK Statistik Parametrik, Surabaya, 2006. 